\title{
Monocyte urokinase expression: modulation by interleukins
}

\author{
Margaret R. Gyetko,*,† Camille C. Wilkinson,* and Robert G. Sitrin ${ }^{\dagger}$ \\ *Pulmonary Section, Department of Veterans Affairs Medical Center, and ${ }^{\dagger}$ Pulmonary and Critical Care Medicine Division, \\ Department of Internal Medicine, University of Michigan Medical Center, Ann Arbor
}

\begin{abstract}
This study delineates the regulatory effect of interleukin-1 (IL-1) and interleukin-2 (IL-2) on monocyte plasminogen activator (PA) activity. Mononuclear phagocytes regulate net $P A$ activity by modulating the expression of urokinase-type PA (uPA) and a specific plasminogen activator inhibitor, PAI-2. To understand the regulation of mononuclear phagocyte PA activity, it is important to compare the expression of uPA and PAI-2. In this study, we determined the relative abundance of secreted PA and PA inhibitor activity in human monocyte-conditioned medium after stimulation with human recombinant IL-1 or IL-2. In agreement with our previous description of tumor necrosis factor- $\alpha$ and interferon$\gamma$ stimulation of mononuclear phagocytes, we found no detectable PA activity in conditioned medium. Both IL-1 and IL-2 had dose-dependent effects, significantly upregulating PA inhibitor activity in monocyte-conditioned medium (up to 11-fold). To further investigate the mechanism underlying this effect, Northern blot analysis was done to measure steady-state mRNA for UPA and PAI-2. Consistent with the increase in secreted PA inhibitor activity, we found that both IL-1 and IL-2 significantly increased steady-state mRNA for PAI-2. In addition, however, both IL-1 and IL-2 increased steady-state mRNA for uPA. IL-1 appears to increase mRNA for uPA to a greater extent than does IL-2. We conclude that IL-1 and IL-2 modulate monocyte proteolytic activity by increasing expression of uPA and PAI-2 with a resultant predominance of PAI-2. We further conclude that cytokine-specific regulation of plasminogen activity is achieved partly by varying the proportionate expression of uPA and PAI-2. J. Leukoc. Biol. 53: 598-601; 1993.
\end{abstract}

Key Words: cytokines $\cdot$ plasminogen activators $\cdot$ plasminogen activator inhibitors $\cdot$ proteolysis

The formation of plasmin by plasminogen activators is crucial for the orderly generation and resolution of inflammation [1-4]. Local plasminogen activation by urokinase-type plasminogen activator (uPA) is a mechanism by which inflammatory leukocytes degrade extracellular matrix and traverse tissue planes. The generation of plasmin is important in tissue remodeling, as it degrades fibrin matrix and activates elastases and collagenases [5-8]. uPA itself is chemotactic for neutrophils and mitogenic for lymphocytes $[9,10]$. Furthermore, it is likely the uPA modulates the release and activity of inflammatory cytokines. Thus, the expression of PA activity is intimately involved in the course of the inflammatory response by directing inflammatory cell trafficking, matrix remodeling, and cytokine-mediated cellto-cell signaling. There is substantial evidence that disordered plasmin generation is instrumental in the generation of acute and chronic lung injury [11-14]. Therefore, it is essential that we understand how cells regulate PA activity in the context of inflammation. We previously demonstrated that the inflammatory cytokines tumor necrosis factor (TNF) and interferon (IFN) modulate the expression of PA activity through the coordinated expression of uPA and plasminogen activator inhibitor PAI-2 [15]. In this study, we extend this investigation to the regulation of monocyte PA activity by interleukins 1 and 2 (IL-1 and IL-2), mediators that figure importantly in the early propagation of inflammatory and immune signals. Among other effects, IL-1 enhances production of IL-2 and IL-2 receptor in antigen-stimulated T cells, up-regulates granulocyte-macrophage colony-stimulating factor synthesis in bronchial epithelial cells, and increases expression of adhesion molecules on the surface of endothelial cells. IL-2 also has multiple effects, including enhanced $\mathrm{T}$ cell expression of class II major histocompatibility antigens, proliferation, and lymphokine secretion [16, 17].

For this study, plasminogen was prepared from outdated human plasma by lysine-Sepharose affinity chromatography (Pharmacia Chemicals, Piscataway, NJ) [18]. Plasminogen preparations were rendered free of active plasmin by treatment with phenylmethylsulfonyl fluoride $(1 \mathrm{mM})$ for $16 \mathrm{~h}$ at $25^{\circ} \mathrm{C}$, followed by extensive dialysis in $0.05 \mathrm{M}$ phosphate buffer, $\mathrm{pH}$ 7.5. The human PAI-2 cDNA, generously provided by Andrew C. Webb (Department of Biological Sciences, Wellesley College, Wellesley, MA), was the subcloned internal PstI-DraI fragment of the pcD-1214 clone in pGEM-2 (Promega, Madison, WI), inserted between the PstI and SmaI sites in the polylinker [19]. Human urokinase cDNA was obtained from the Japanese Center Resources Bank-Gene, National Institute of Health, Tokyo [20]. This is a near-full-length clone inserted in the PstI-PvuII site of pcD. Human recombinant IL-1 and IL-2 were purchased from Genzyme, Boston, MA. Culture medium and additives were found to contain less than 0.1 endotoxin unit $/ \mathrm{ml}$, as determined by a Limulus amebocyte lysate assay (Sigma, St. Louis, MO).

Human peripheral blood monocytes were purified from buffy coats, provided by the American Red Cross (Detroit, MI), by density gradient centrifugation [15]. Cell number was determined by counting in a hemocytometer and viability was assessed by trypan blue exclusion. Differential cell counts were determined by examining Giemsa-stained cytocentrifuge samples. Mononuclear cells were resuspended at $2 \times 10^{6} \mathrm{cells} / \mathrm{ml}$ in complete medium consisting of RPMI 1640 supplemented with penicillin $(100 \mathrm{U} / \mathrm{ml})$, streptomycin $(100 \mu \mathrm{g} / \mathrm{ml})$, gentamicin $(100 \mu \mathrm{g} / \mathrm{ml})$, L-glutamine $(2 \mathrm{mM})$, and $0.1 \%$ human serum albumin (American Red Cross),

\footnotetext{
Abbreviations: IFN, interferon; IL-1, interleukin-1; PA, plasminogen activator; PAI-2, plasminogen activator inhibitor; PMA, phorbol myristate acetate; TNF, tumor necrosis factor; uPA, urokinase-type PA.

Reprint requests: Margaret R. Gyetko, Pulmonary and Critical Care Medicine Division, University of Michigan Medical Center, Ann Arbor, MI 48109-0360.

Received February 22, 1993; accepted March 16, 1993.
} 
and the monocytes were purified by adherence in $16-\mathrm{mm}$ plastic dishes (Corning, Corning, NY) at $5 \times 10^{6}$ cells/well (approximately $2 \times 10^{6}$ monocytes) for $2 \mathrm{~h}$ in humidified air containing $5 \% \mathrm{CO}_{2}$ at $37^{\circ} \mathrm{C}$. Nonadherent cells were removed by washing with RPMI 1640 at $37^{\circ} \mathrm{C}$.

Adherent monocytes were cultured in the medium above with various doses of IL-1 and IL-2. The conditioned media were then removed and the PA and PA inhibitor activities determined by esterolytic assays. As an internal quality control for each experiment, monocytes were cultured in parallel wells with $10 \mathrm{ng} / \mathrm{ml}$ phorbol myristate acetate (PMA) to ensure that there was the expected increase in PA inhibitor activity [21]. On occasion, cells were refractory to PMA and were considered to be either endogenously activated or injured during purification. Data derived from these cell preparations were not used.

Plasminogen activator activity was measured with the esterolytic assay of Coleman and Green [22], with minor adaptations for use in 96-well plates as previously described [15]. Briefly, samples were mixed with an optimal amount of plasminogen in buffer containing glycine, bovine serum albumin, Tris, and Triton and incubated at $37^{\circ} \mathrm{C}$ for $30 \mathrm{~min}$. The plasmin generated by this step was then quantified by the addition of a synthetic plasmin substrate and a color reagent. After $30 \mathrm{~min}$ at $37^{\circ} \mathrm{C}$, optical absorbance was read at $414 \mathrm{~nm}$ with a multichannel spectrophotometer (Flow Labs, McLean, VA). After subtracting control values of wells lacking test samples, PA activity was determined from a standard curve generated with commercially prepared urokinase (Calbiochem) and expressed in milliPloug units (mPU).

By modifying the esterolytic assay, we can measure either PA or PA inhibitor activity in conditioned media [4]. To measure PA inhibitor activity, serial dilutions of the test samples were coincubated with $2 \mathrm{mPU}$ of urokinase and the residual PA activity was measured in standard fashion. PA inhibitor activity was calculated from a plot of the sample concentration (reciprocal of the dilution factor) versus residual PA activity and expressed as PA inhibitor units $/ \mathrm{ml}$ (1 PAI unit = $1 \mathrm{mPU}$ PA inhibited). Endogenous PA activity was included with the exogenous $2 \mathrm{mPU}$ when calculating PA inhibition.

For mRNA analysis, human monocytes were purified from mononuclear cells by adherence to $60-\mathrm{mm}$ plastic tissue culture dishes (Corning). The adherent monocytes $\left(8 \times 10^{6}\right.$ monocytes/dish) were incubated for $4 \mathrm{~h}$ in medium in the presence and absence of IL-1 $(250 \mathrm{U} / \mathrm{ml})$ and IL-2 (100 $\mathrm{U} / \mathrm{ml}$ ). The medium was then removed and the monocytes lysed directly in the culture dish by repeated pipet aspiration in 4.23 M guanidine isothiocyanate (IBI, New Haven, CT), $0.5 \%$ sarcosyl, $25 \mathrm{mM}$ citric acid, and $0.72 \% 2$-mercaptoethanol. The RNA was purified by phenol-chloroform extraction and precipitation at $-20^{\circ} \mathrm{C}$ in isopropanol and $\mathrm{Na}$ acetate [23]. The RNA pellet was suspended in RNAse-free water and the concentration determined by spectroscopy at $260 \mathrm{~nm}$

The RNA was size fractionated electrophoretically on $1 \%$ agarose gels containing $3.5 \mu \mathrm{M}$ formaldehyde and $20 \mathrm{pg} / \mathrm{ml}$ ethidium bromide [24]. Visualization of ribosomal bands under ultraviolet (UV) light provided internal size markers for each lane and also confirmed that RNA loading was equal among lanes. The RNA was transferred to Hybond nylon filters (Amersham, Arlington Heights, IL) according to the method of Southern and fixed by exposure to UV light [24]. The cDNA of interest was labeled with [ $\left.{ }^{32} \mathrm{P}\right] \mathrm{dCTP}$ (Amersham) by random priming, achieving specific activities of approximately $5 \times 10^{8} \mathrm{cpm} / \mu \mathrm{g}$ DNA [25]. The nylon filters were then hybridized with $2 \times 10^{7} \mathrm{cpm}$ of $\left[{ }^{32} \mathrm{P}\right] \mathrm{cDNA}$ for $18 \mathrm{~h}$ at $65^{\circ} \mathrm{C}$, followed by serial washes of increasing stringency, the final wash consisting of $0.1 \times$ standard saline citrate, $0.1 \%$ sodium dodecyl sulfate at $68^{\circ} \mathrm{C}$ [24]. The filters were then developed by autoradiography, using Kodak XAR-5 X-Omat AR film at $-70^{\circ} \mathrm{C}$ (Eastman Kodak, Rochester, NY).

Comparisons between groups were performed using a paired Student's $t$-test to compensate for interdonor variability in the levels of PA inhibitor activities expressed under control conditions [26]. The data were log transformed to ensure equivalent variances between groups. Data are expressed as mean \pm SEM.

Adherent cell preparations were routinely more than $94 \%$ monocytes and greater than $95 \%$ viable. After incubation in serum-free medium for $24 \mathrm{~h}$, even at the highest concentrations of IL-1 $(500 \mathrm{U} / \mathrm{ml})$ and IL-2 $(500 \mathrm{U} / \mathrm{ml})$, cells were routinely greater than $90 \%$ viable.

To determine the effects of IL-1 on PA and PA inhibitor expression, conditioned media were assayed after incubation for $24 \mathrm{~h}$ with $0-500 \mathrm{U} / \mathrm{ml}$ human recombinant IL-1. There was no detectable PA activity in monocyte-conditioned media under either control or IL-1-stimulated conditions.
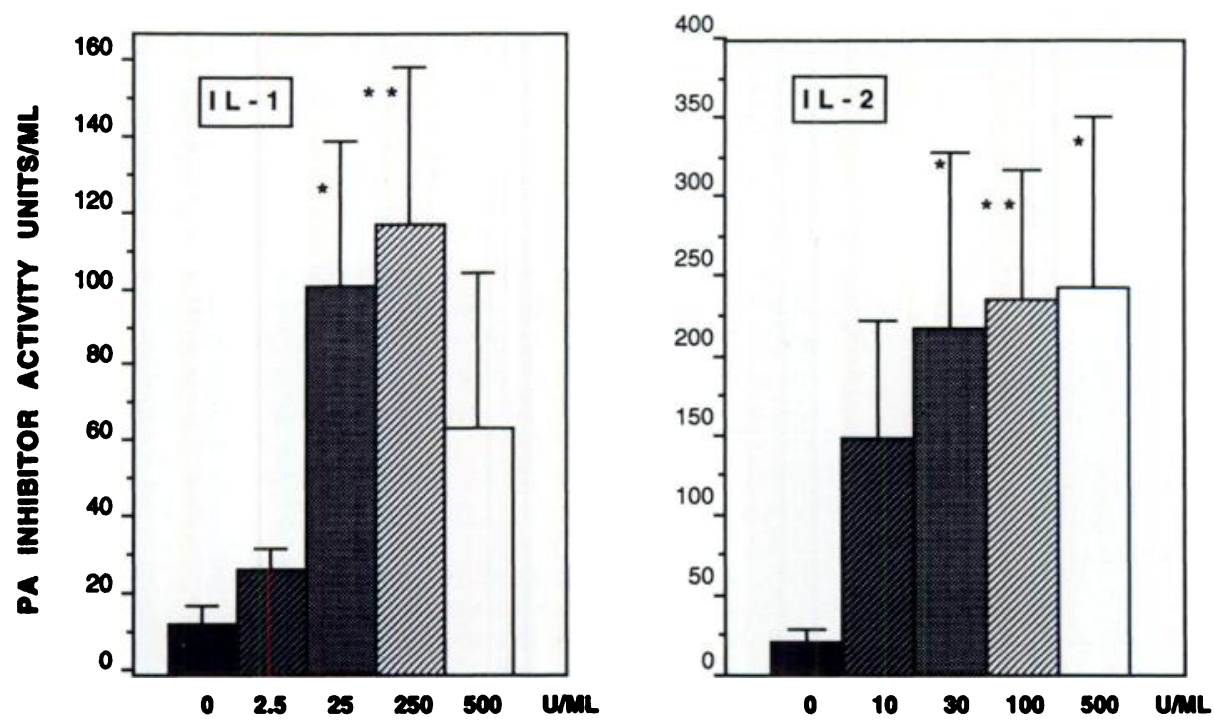

Fig. 1. PA inhibitor activities of IL-1- or IL-2-stimulated monocytes. Both IL-1 and IL-2 induced a dose-related increase in PA inhibitor activities. One PA inhibitor activity unit is equal to inhibitor sufficient to inhibit 1 milliploug unit of PA activity. IL-1: ${ }^{*} P<.05, \quad{ }^{* *} P<.01 . \quad$ IL-2: $\quad * P<.05$, $* P<.001$. 

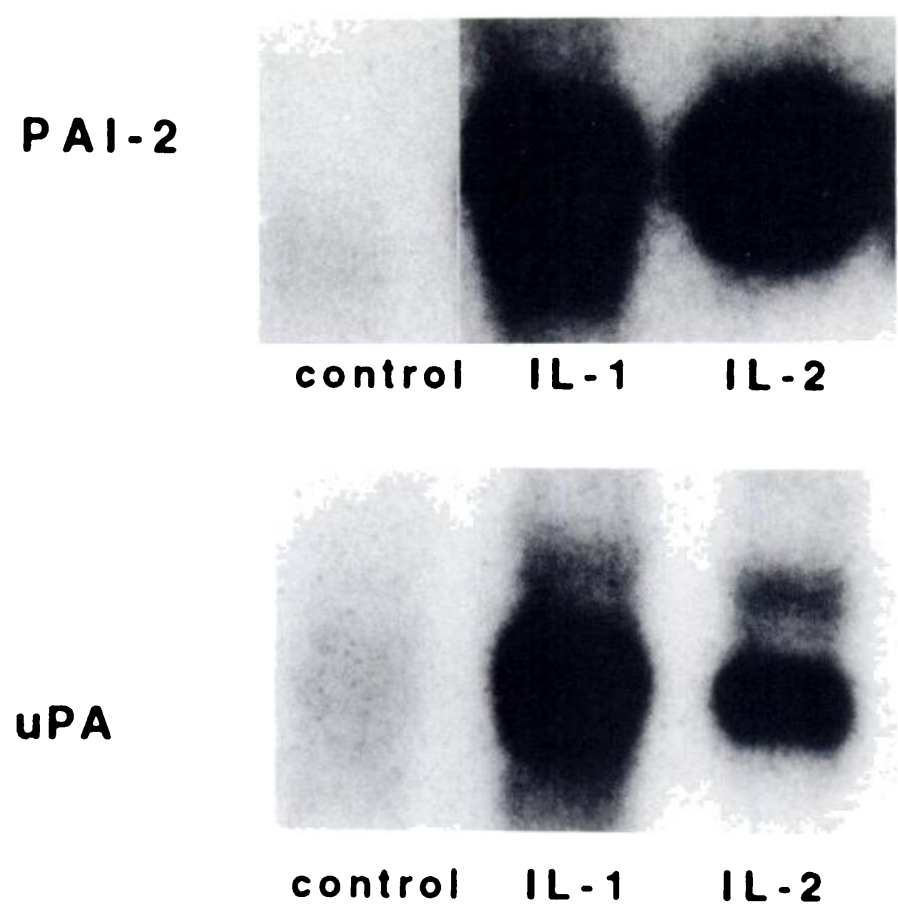

Fig. 2. Effects of IL-1 and IL-2 on normal human monocytes. Northern blot analysis shows that stimulation with either IL-1 or IL-2 increases mRNA for PAI-2 and UPA.

Conditioned media of control monocytes, however, contained a small amount of PA inhibitor activity $(12.75 \pm 4.43$ PAI units $/ \mathrm{ml}$ ). IL-1 induced a dose-dependent increase in PA inhibitor activity that reached a maximum at $250 \mathrm{U} / \mathrm{ml}$ $(113.33 \pm 40.19$ PAI units $/ \mathrm{ml} ; P<.01)$ (Fig. 1$)$.

Monocytes were stimulated with 0-500 $\mathrm{U} / \mathrm{ml}$ human recombinant IL-2 for $24 \mathrm{~h}$ to determine the effects on secreted PA and PA inhibitor activities. There was no detectable PA activity in monocyte-conditioned media under either control or IL-2-stimulated conditions. IL-2 produced a dose-dependent increase in PA inhibitor activity that reached a statistical maximum at $100 \mathrm{U} / \mathrm{ml}$ compared to control $(236.01 \pm 82.73$ compared to control, $20.83 \pm 7.58$; $P<.001$ ) (Fig. 1).

Because both IL-1 and IL-2 induced an abundant increase in PA inhibitor activity, effects on PA activity may have been obscured by excess inhibitor in conditioned media. Therefore, to further evaluate for modulation of PA activity by interleukins, we evaluated levels of steady-state mRNA for UPA and PAI-2 by Northern blotting. Monocytes were incubated with optimal concentrations of IL-1 $(250 \mathrm{U} / \mathrm{ml})$ or IL-2 $(100 \mathrm{U} / \mathrm{ml})$ for $6 \mathrm{~h}$ prior to lysis and RNA extraction as detailed earlier. The same filters, stripped and reprobed, were used for determination for both UPA and PAI-2. In keeping with the observed increases in PA inhibitor activity, both IL-1 and IL-2 increased mRNA for PAI-2. IL-1 and IL-2 also increased uPA mRNA, compared to controls (Fig. 2). It is most likely that either the excess PA inhibitor in monocyte-conditioned media irreversibly inactivates secreted UPA or that the UPA secreted in response to IL-1 or IL-2 is entirely bound to uPA cell surface receptors and is therefore not present in conditioned media. These data do not exclude the possibility that an alteration in intracellular protein processing may result in a block of uPA protein expression. IL-1 and IL-2 appear to induce similar increases in PAI-2 mRNA. IL-1, however, appears to increase uPA
mRNA more than does IL-2. In the IL-1 circumstance, PA inhibitor activity would be expected to be offset by the presence of PA. This offers a potential explanation for the greater PA inhibitor activity observed when monocytes are simulated with IL-2 compared to IL-1. We recently reported that stimulation with TNF increases UPA mRNA in mononuclear phagocytes to a greater extent than stimulation with IFN but does not increase secretion of uPA protein proportionately [15]. It is of considerable interest that we see a similar pattern of regulation using IL-1 and IL-2, another monokine-lymphokine pair. Further work is needed to determine whether the mechanisms regulating monocyte PA activity differ depending on whether the modulatory signals are of an autocrine or paracrine nature.

In summary, we have demonstrated that IL-1 and IL-2 modulate the expression of monocyte proteolytic activity by enhancing secreted-phase PA inhibitor activity and by increasing steady-state mRNA for UPA and PAI-2 in an interleukin-specific manner. By determining the precise mechanism by which mononuclear phagocytes regulate proteolytic activity in response to immunologic mediators, it will be possible to better characterize the interactions between the fibrinolytic system and cytokine networks during inflammation.

\section{ACKNOWLEDGMENT}

This work was supported by a Merit Review Grant from the Research Service of the Department of Veterans Affairs.

\section{REFERENCES}

1. Chapman, H.A., Yang, X., Sailor, L., Sugarbaker, D. (1990) Expression of plasminogen activator inhibitor type 1 by human alveolar macrophages. Am. Rev. Respir. Dis. 141, A97.

2. Dan $\phi$, K., Andreasen, P.A., Gr $\phi$ ndahi-Hansen, J., Kristensen, P., Nielsen, L.S., Skriver, L. (1985) Plasminogen activators, tissue degradation, and cancer. Adv. Cancer Res. 44, 139.

3. Ginsburg, D., Zeheb, R., Yang, A.Y., Rafferty, U.M., Andreasen, P.A., Nielsen, L., Dan $\phi$, K., Lebo, R.V., Gelehrter, T.D. (1986) cDNA cloning of human plasminogen activatorinhibitor from endothelial cells. J. Clin. Invest. 78, 1673.

4. Vassalli, J.D., Dayer, J.M., Wohlwend, A., Belin, D. (1984) Concomitant secretion of prourokinase and of a plasminogen activator-specific inhibitor by cultured human monocytesmacrophages. J. Exp. Med. 159, 1653.

5. Chapman, H.A., Stone, O.L. (1984) Cooperation between plasmin and elastase in elastin degradation by intact murine macrophages. Biochem. J. 222, 721.

6. Liotta, L.A., Goldfarb, R.H., Brundange, R., Siegal, G.P., Terranova, V., Garbisa, S. (1981) Effect of plasminogen activator (urokinase), plasmin, and thrombin on glycoprotein and collagenous components of basement membrane. Cancer Res. 41, 4629.

7. Senior, R.M., Shapiro, S.D. (1992) Introduction: the matrix metalloproteinase family. Am. J. Respir. Cell. Mol. Biol. 7, 119.

8. Werb, Z., Mainardi, C.L., Vater, C.A., Harris, E.D. (1977) Endogenous activation of latent collagenase by synovial cells: evidence for a role for plasminogen activator. N. Engl. J. Med. 296, 1017.

9. Cohen, S.D., Israil, E., Spiess-Meier, B., Wainberg, M.A. (1981) Plasminogen activator is an apparent lymphocyte mitogen. J. Immunol. 126, 1415.

10. Boyle, M.D.P., Chiodo, V.A., Lawman, M.J.P., Gee, A.P., Young, M. (1987) Urokinase: a chemotactic factor for polymorphonuclear leukocytes in vivo. J. Immunol. 139, 169.

11. Sitrin, R.G., Brubaker, P., Fantone, J.C. (1987) Tissue fibrin 
deposition during acute lung injury in rabbits and its relationship to local expression of procoagulant and fibrinolytic activities. Am. Rev. Respir. Dis. 135, 930.

12. Wilson, B.D., Huang, C.J., Moore, V.L., Calvanico, N.J. (1982) The development of granulomatous pulmonary inflammation in rabbits by aerosol challenge. Cell. Immunol. 67, 90.

13. Hasday, J.L., Bachwich, P.R., Lynch, J.P., Sitrin, R.G. (1988) Procoagulant and plasminogen activator activities of bronchoalveolar fluid in patients with pulmonary sarcoidosis. Exp. Lung Res. 14, 261.

14. Bertozzi, P., Astedt, B., Zenzius, L., Lynch, K., LeMaire, F., Zapol, W., Chapman, H.A. (1990) Depressed bronchoalveolar urokinase activity in patients with adult respiratory distress syndrome. N. Engl. J. Med. 322, 890.

15. Gyetko, M., Shollenberger, S., Sitrin, R. (1992) Urokinase expression in mononuclear phagocytes: cytokine-specific modulation by interferon gamma and tumor necrosis factor-alpha. J. Leukoc. Biol. 51, 256.

16. Arai, K., Lee, F., Miyajima, A., Miyatake, S., Arai, N., Yokota, $T$. (1990) Cytokines: coordinators of immune and inflammatory responses. Annu. Rev. Biochem. 59, 783.

17. Marini, M., Soloperto, M., Mezzetti, M., Fasoli, A., Mattoli, S. (1991) Interleukin-1 binds to specific receptors on human bronchial epithelial cells and upregulates granulocyte/macrophage colony-stimulating factor synthesis and release. $A m$. J. Cell. Mol. Biol. 4, 519.

18. Deutsch, D.G., Mertz, E.T. (1970) Plasminogen: purification from human plasma by affinity chromatography. Science 170 , 1095.
19. Webb, A.C., Collins, K.L., Snyder, S.E., Alexander, S.J., Rosenwasser, L.J., Eddy, R.L., Shows, T.B., Auron, P.E. (1987) Human monocyte Arg-Serpin cDNA: sequence, chromosomal assignment, and homology to plasminogen activator-inhibitor. J. Exp. Med. 166, 77.

20. Riccio, A., Grimaldi, G., Verde, P., Sebastio, G., Boast, S., Blasi, F. (1985) The human urokinase-plasminogen activator gene and its promoter. Nucleic Acids Res. 13, 2759.

21. Schleuning, W., Medcalf, R., Hession, C., Rothenbuhler, R., Shaw, A., Kruithof, E. (1987) Plasminogen activator inhibitor 2: regulation of gene transcription during phorbol ester-mediated differentiation of U-937 human histiocytic lymphoma cells. Mol. Cell. Biol. 7, 4564.

22. Coleman, P.L., Green, G.D.J. (1981) A sensitive, coupled assay for plasminogen activator using a thiol ester substrate for plasmin. Ann. N.Y. Acad. Sci. 370, 617.

23. Chomczynski, P., Sacchi, P. (1987) Single step method of RNA isolation by acid guanidinium thiocyanate-phenol-chloroform extraction. Anal. Biochem. 162, 156.

24. Maniatis, T., Frisch, E.T., Sambrook, J. (1982) Molecular Cloning: A Laboratory Manual. Cold Spring Harbor Laboratory, Cold Spring Harbor, NY.

25. Feinberg, A.P., Vogelstein, B. (1983) A technique for radiolabelling DNA restriction endonuclear fragments to high specific activity. Anal. Biochem. 132, 6.

26. Zar, J.H. (1984) Biostatistical Analysis. Prentice-Hall, Englewood Cliffs, NJ. 